\title{
IgG subclass specific antibody response in recurrent bronchitis
}

F de Baets, R Pauwels, I Schramme, J Leroy

\begin{abstract}
The IgG subclass specific immune response against pneumococcal type 3 polysaccharide antigen before and after immunisation in healthy children and children with recurrent bronchitis was studied. Recurrent bronchitis was defined as three or more episodes a year, during at least two consecutive years, of bronchopulmonary infection, productive cough with or without fever, and/or diffuse rales by physical examination. Twenty five patients and 15 healthy children were selected.

The patient group had lower concentrations of $I_{g} G_{1}$ and $I_{g} G_{2}$ specific pneumococeal antibodies compared with healthy children, regardless of whether or not the total $\mathbf{I g G}_{2}$ concentration was low. The children with recurrent bronchitis showed a greater increase in $I_{g} G_{1}$ and $I g G_{2}$ antibodies after immunisation than the controls.
\end{abstract}

It is concluded that children with recurrent bronchitis show a decreased humoral immune response to pneumococcal type 3 polysaccharide antigen. This finding suggests that a defect in the humoral immune response against polysaccharide antigens is an important cause of recurrent bronchitis in childhood.

A high incidence of $\operatorname{IgG}_{2}$ subclass deficiency is reported in children with recurrent upper and lower respiratory tract infections. ${ }^{1-6}$ Antibodies against polysaccharide antigens are mainly found in the $\mathrm{IgG}_{2}$ subclass. ${ }^{7-10}$ Polysaccharide antigens are the main antigenic determinants of encapsulated bacteria such as Haemophilus influenzae and Streptococcus pneumoniae; the latter is a major cause of recurrent respiratory infections. In $\operatorname{IgG}_{2}$ deficient children, the humoral immune response after immunisation with a polysaccharide antigen is significantly decreased. ${ }^{1-14}$ Ambrosino et al reported a patient with recurrent bacterial pneumonia, normal concentrations of immunoglobulin classes and subclasses, but a significantly decreased immune response against polysaccharide antigens. ${ }^{15}$ This suggested a functional disorder in humoral immunity. Recently some authors observed a decreased antibody response after immunisation with a polysaccharide antigen in children with recurrent infections without any immunoglobulin class or subclass deficiency. ${ }^{16-18}$ Therefore we were interested in the serum concentrations of IgG subclass specific antibodies against type 3 polysaccharide antigen before and after immunisation in children with recurrent bronchitis.

\section{Patients and methods}

PATIENTS

Because a formal definition of recurrent bronchitis in childhood is lacking, we defined it as three or more episodes a year, during at least. two consecutive years, of bronchopulmonary $\overrightarrow{\vec{\omega}}$ infection, productive cough with or without $O$ fever, and/or diffuse rales by physical examin- 응 ation. In order to avoid the inclusion of mainly asthmatic patients, wheezy or dyspnoeic children were excluded and children had to be at least $3 \vec{N}$ years old. Asthma as the aetiological factor in $\vec{\omega}$ recurrent respiratory symptoms is usually $\infty$ recognised clinically by 3 years. ${ }^{19}$

According to this definition 25 children (15 boys) (mean age 57 months, range 36-105) were selected. Thirteen patients were attending the $\varnothing_{\varnothing}$ outpatient department of the paediatric respiratory clinic at the University Hospital, Ghent; 12 Ф were residents in an asthma centre at De Haan, Belgium.

Respiratory symptoms were first seen at the mean age of 7 months. The mean annual rate of episodes of respiratory symptoms was 10 . In $84 \%$ of the children, fever was a constant sign $\bar{\partial}$ during symptom episodes. Sixty percent of the $\frac{\mathrm{D}}{\Phi}$ patients had recurrent pneumonia and in $72 \% \propto$ there was no seasonal occurrence of symptoms. There was a family history of chronic bronchitis in a first degree relative in $36 \%$ of the children, with atopy and/or asthma in $56 \%$. There was a combination of both chronic bronchitis and asthma in more than one first degree relative in $12 \%$. Adenoids and tonsils were removed in $48 \%$ and $28 \%$ of the patients respectively.

In $40 \%$ of the patients total IgE serum concentrations were higher than $2 \mathrm{SD}$ above the mean for age. ${ }^{20}$ Eight percent showed one or more positive radioallergosorbent tests. Sweat tests gave negative results in all children. Ciliary function was examined on bronchial of biopsy specimens or nasal swabs in 15 children. $N$ The immotile cilia syndrome was diagnosed in $\mathrm{W}$ one patient. Gastro-oesophageal reflux was found in four of the 15 children tested. Forty 0 eight percent of the patients showed persistent abnormalities on radiographs of the thorax. Persisting radiological signs consisted of atelectasis or infiltration of the right middle lobe and/or lingula. Bronchoscopy was performed in 12 children and $H$ influenzae was cultured from bronchoalveolar lavage fluid in two patients. Severe signs of chronic bronchitis were found in 8 all of the patients (that is, hypersecretion, pale mucosae, hypertrophic submucosal glands, longitudinal mucosal folds). Six of the nine $\rightleftharpoons$ children in whom a bronchography was done showed bronchiectasis. 
A control group of 15 children, mean age 71 months (range 36-144), was enrolled. The parents of 640 children in an infant and elementary school were informed of the study and asked for their cooperation. All control children were selected after they had returned a questionnaire in which the proneness to upper and lower respiratory tract infection was evaluated. Only children with two or fewer yearly episodes of bronchitis, rhinitis, sinusitis, or otitis were accepted. Children with a history of pneumonia or any infectious disease within one month before the start of the study were excluded. No significant difference in mean age between groups was observed (Student's $t$ test).

Patients and control children were immunised with a pneumococcal vaccine (Pneumovax 23, Merck Sharp and Dohme). Serum samples were taken before and one month after immunisation.

\section{METHODS}

IgG subclasses were measured by enzyme linked immunosorbent assay (ELISA) using monoclonal antibodies. The latter were obtained from the Binding Site Limited (Birmingham). The specificity of these monoclonal antibodies was tested as reported by Jefferis and Reimer. ${ }^{21}$ Each serum sample was studied twice and a sample from a normal serum pool was included in every assay plate. A standard curve was constructed for each subclass using a reference preparation supplied by the World Health Organisation (SPSO1). The intra-assay coefficient of variation was $7 \%, 5 \%, 4 \%$, and $7 \%$ for $\mathrm{IgG}_{1}, \mathrm{IgG}_{2}, \mathrm{IgG}_{3}$, and $\mathrm{IgG}_{4}$ respectively. The interassay coefficient of variation was $13 \%$, $12 \%, 18 \%$, and $15 \%$ for $\operatorname{IgG}_{1}, \mathrm{IgG}_{2}, \mathrm{IgG}_{3}$, and $\mathrm{IgG}_{4}$ respectively. Our own reference values for IgG subclasses in different age groups are given in table 1 . Sera were obtained from 175 healthy children aged 0 to 18 years at the time of visiting the paediatric outpatient department for noninfectious or non-inflammatory diseases or when they were admitted for elective surgery. All control children were selected after they had answered a questionnaire in which the proneness to upper and lower respiratory tract infection was evaluated as mentioned above. If $\mathrm{C}$ reactive protein concentration was greater than $10000 \mu \mathrm{g} / \mathrm{l}$ or $\alpha_{2}$ globulin was higher than 0.9

Table 1 Reference values for IgG subclasses in different age groups. Values are mean (range:mean and $2 S D$ ) in $g / l$

\begin{tabular}{|c|c|c|c|c|}
\hline $\begin{array}{l}\text { Age } \\
\text { (years) }\end{array}$ & $I g G_{I}$ & $I g G_{2}$ & $I g G_{3}$ & $I g G_{4}$ \\
\hline $0-0 \cdot 5$ & $2.35(0.85-6.50)$ & $1.08(0 \cdot 13-8 \cdot 73)$ & $0 \cdot 18(0.03-0.93)$ & $0.11(0.02-0.58)$ \\
\hline$>0.5-1$ & $4.05(1 \cdot 43-11 \cdot 49)$ & $0.73(0.22-2.46)$ & $0.35(0 \cdot 11-1 \cdot 10)$ & $0.05(0.01-0.19)$ \\
\hline$>1-<3$ & $3.50(1.54-7.94)$ & $0.88(0 \cdot 36-2 \cdot 17)$ & $0 \cdot 33(0 \cdot 10-1 \cdot 12)$ & $0.06(0.02-0.39)$ \\
\hline $3-<5$ & $5 \cdot 74(2 \cdot 23-14 \cdot 78)$ & $1.44(0.51-4.09)$ & $0.38(0 \cdot 10-1 \cdot 43)$ & $0.25(0.05-0.14)$ \\
\hline $\begin{array}{r}5-<7 \\
(n=22)\end{array}$ & $6.44(2.02-21.67)$ & $1.48(0.46-4.77)$ & $0.42(0.13-1 \cdot 35)$ & $0.34(0.05-2 \cdot 12)$ \\
\hline $7-<10$ & $6.52(2 \cdot 73-15 \cdot 56)$ & $1.51(0.49-4.66)$ & $0.42(0 \cdot 14-1 \cdot 23)$ & $0.24(0.03-1.99)$ \\
\hline $\begin{array}{c}10-<13 \\
(n=23)\end{array}$ & $5.68(3.08-9.22)$ & $1 \cdot 88(0.69-5 \cdot 13)$ & $0.44(0 \cdot 16-1 \cdot 20)$ & $0.23(0.02-2.49)$ \\
\hline $\begin{array}{c}13-<17 \\
(n=26)\end{array}$ & $6 \cdot 24(3 \cdot 40-11 \cdot 11)$ & $3.09(0.95-9.98)$ & $0.55(0 \cdot 27-1 \cdot 14)$ & $0 \cdot 20(0.02-2 \cdot 52)$ \\
\hline$\geqslant=17$ & $6.01(3.57-10 \cdot 11)$ & $4 \cdot 60(1 \cdot 23-17 \cdot 10)$ & $0.54(0.23-1.25)$ & $0.20(0.03-1 \cdot 10)$ \\
\hline
\end{tabular}

g/l the serum sample was omitted as a control. As immunoglobulin concentrations are not distributed normally, geometric means and normal ranges of the concentrations for each subclass were calculated for each age group from the logarithm of the experimental values. ${ }^{22}$ Total serum immunoglobulins were measured by nephelometry. Patients were considered deficient for an immunoglobulin class or an IgG subclass if they had values more than $2 \mathrm{SD}$ below the geometric mean for age matched healthy subjects. Total IgE and specific IgE were measured by radioimmunoassay. Ciliary function was examined on bronchial biopsy specimens or nasal swabs in the laboratory of $\mathrm{Dr}$ $S$ van der Baan, Amsterdam, The Netherlands. ${ }^{23}$ Sweat chloride was measured by the method of Gibson and Cooke. ${ }^{24}$ Gastro-oesophageal reflux was evaluated by the Tuttle test. ${ }^{25}$

Subclass specific pneumococcal antibodies were measured by ELISA. Microtitre plates (Nunc, Maxisorp) were coated with $0.1 \mathrm{ml}$ of type 3 pneumococcal polysaccharide (American Type Culture Collection), $10 \mu \mathrm{g} / \mathrm{ml}$, dissolved in a barbital buffer, diluted 1:100 in distilled water. The plates were incubated for 96 hours at $37^{\circ} \mathrm{C}$ and kept at $4^{\circ} \mathrm{C}$ until used. A standard curve for different IgG subclasses was formed with a standard serum (Janssen Biochemico, Belgium). Dilutions $1 / 100,1 / 200,1 / 400,1 / 800$, $1 / 2000,1 / 4000,1 / 8000,1 / 10000$, and a blank for $\mathrm{IgG}_{1}$ and dilutions $1 / 10,1 / 20,1 / 40,1 / 80$, $1 / 200,1 / 400,1 / 800,1 / 1000$, and a blank for $\mathrm{IgG}_{2}, \mathrm{IgG}_{3}$, and $\mathrm{IgG}_{4}$ were obtained. Serum samples of patients and controls were diluted $1 / 200,1 / 500$, and $1 / 1000$ for $\operatorname{IgG}_{1}$ and $1 / 40$ and $1 / 80$ for $\operatorname{IgG}_{2}, \operatorname{IgG}_{3}$, and $\operatorname{IgG}_{4}$ antibodies. After washing, microtitre plates were incubated with serum samples and standard samples $0.1 \mathrm{ml}$ for three hours at $37^{\circ} \mathrm{C}$.

Subclass specific pneumococcal antibodies were measured with monoclonal subclass specific antibodies (Janssen). These monoclonal antibodies were conjugated with horseradish peroxidase. The conjugate was diluted $1 / 2500$ for $I g G_{1}, 1 / 500$ for $\operatorname{IgG}_{2}$ and $\operatorname{IgG}_{3}$, and $1 / 250$ for $\mathrm{IgG}_{4}$. After washing, diluted conjugate was added to the microtitre plates and incubated for two hours at room temperature. Microtitre plates were washed five times and $0.1 \mathrm{ml}$ substrate was added. After 30 minutes of incubation at room temperature the reaction was stopped by $0.05 \mathrm{ml}$ of $2 \mathrm{M}$ sulphuric acid. The extinction coefficient was read on an ELISA reader at $492 \mathrm{~nm}$. As well as a standard curve for subclass specific pneumococcal antibodies, a standard curve for the specific IgG subclass tested was also obtained in every plate. For $\operatorname{IgG}_{1}$ dilutions $1 / 5000$ to $1 / 320000$ and for $\mathrm{IgG}_{2}, \mathrm{IgG}_{3}$, and $\mathrm{IgG}_{4} 1 / 100$ to $1 / 10000$ were used. Extinction coefficients measured for subclass specific antibodies were also read on the simultaneous measured standard curve for the specific IgG subclass. After adjusting for the dilutions used a quantitative value for the specific pneumococcal antibodies could be obtained.

The interassay coefficient of variation for IgG subclass specific pneumococcal antibodies was $12 \%, 15 \%$, and $15 \%$ for $\operatorname{IgG}_{1}, \operatorname{IgG}_{2}$, and $\operatorname{IgG}_{4}$ 
Table 2 Mean IgG subclass specific antibody concentrations against pneumococcal polysaccharide type 3 antigen before and after immunisation. Values are mean $(2 \cdot 5-97 \cdot 5$ centiles) in $\mu \mathrm{g} / \mathrm{ml}$

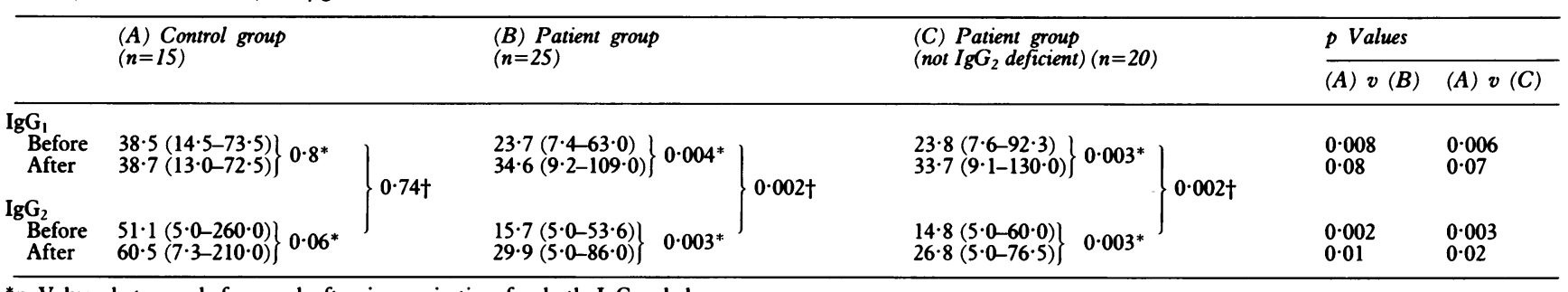

${ }^{*} p$ Values between before and after immunisation for both IgG subclasses.

tp Values between $\operatorname{IgG}_{1}$ and $\mathrm{IgG}_{2}$ before immunisation.

respectively. No measurable concentrations of $\mathrm{IgG}_{3}$ specific pneumococcal antibodies were found.

The significance of differences between groups was determined with the unpaired nonparametric Mann-Whitney U test. Significance of increases in antibody titres after immunisation was evaluated by the paired non-parametric Mann-Whitney U test.

\section{Results}

Two of the 25 patients $(8 \%)$ had a decreased serum concentration for IgG and four $(16 \%)$ had IgA deficiency. IgG subclass deficiency was found in $17(68 \%)$ of the patients with recurrent bronchitis: two (8\%), four (16\%), and seven (28\%) for $\mathrm{IgG}_{2}, \mathrm{IgG}_{3}$, and $\mathrm{IgG}_{4}$ respectively, two $(8 \%)$ for $I G_{2}$ and $I_{g G}$, one $(4 \%)$ for $I_{g G}$ and $\mathrm{IgG}_{4}$, and one for $\mathrm{IgG}_{2}, \mathrm{IgG}_{3}$, and $\mathrm{IgG}_{4}$. No immunoglobulin class or subclass deficiency was found in the healthy control group.

The mean and range of serum antibody concentrations against pneumococcal polysaccharide antigen type 3 in the $\operatorname{IgG}_{1}$ and $\operatorname{IgG}_{2}$ subclass before and after immunisation in patients with recurrent bronchitis, healthy control children, and patients with normal $\mathrm{IgG}_{2}$ concentrations with recurrent bronchitis are shown in table 2 .

Patients with recurrent bronchitis, regardless of whether or not there was an $\mathrm{IgG}_{2}$ deficiency, had lower concentrations of $\operatorname{IgG}_{1}$ and $\operatorname{IgG}_{2}$ specific antibody than the controls. Antibody concentrations before immunisation in the group with recurrent bronchitis were significantly higher for $\operatorname{IgG}_{1}$ than for $\operatorname{IgG}_{2}$. In the control group antibodies before immunisation were higher in the $\operatorname{IgG}_{2}$ subclass, although this was not significant.

Both patient groups showed a greater increase in $\operatorname{IgG}_{1}$ and $\operatorname{IgG}_{2}$ specific antibodies after immunisation than the controls. A $1.9(\mathrm{p}<0.003)$ and $1.2(p<0.06)$ fold increase in $\operatorname{IgG}_{2}$ specific type 3 pneumococcal antibodies was seen after immunisation in the patient (group B) and control group respectively. The mean concentration of $\mathrm{IgG}_{2}$ subclass specific pneumococcal antibodies after immunisation in the patients with recurrent bronchitis remained significantly lower than the mean concentration after immunisation in the control group.

No specific type 3 pneumococcal polysaccharide antibodies were detected in the $\mathrm{IgG}_{3}$ subclass. In some children a low value of specific pneumococcal antibodies was seen in the $\mathrm{IgG}_{4}$ subclass; immunisation did not provoke detectable changes.

\section{Discussion}

Before immunisation antibodies against type 3 o pneumococcal polysaccharide antigen in control ॥ children were mainly of the $\operatorname{IgG}_{2}$ subclass; this is in contrast to those with recurrent bronchitis who had mainly IgG $_{1}$ subclass antibodies. $\vec{v}$ However, antibody concentrations before $\vec{\omega}$ immunisation in both the $\operatorname{IgG}_{1}$ and $\operatorname{IgG}_{2}$ sub- $\infty$ class were significantly lower in the group with 음 recurrent bronchitis. In view of the frequent $\rightarrow$ respiratory infections, one would expect a higher ${ }_{\infty}$ antibody concentration in these children. This $\varnothing_{\varnothing}$ strongly suggests a primary defect in the $\bar{Z}$ humoral immune response in these children.

It is already known that $\operatorname{IgG}_{2}$ deficient $\vec{\theta}$ children have a decreased immune response $\varrho$ against polysaccharide antigens. ${ }^{11-14}$ By omitting IgG $_{2}$ deficient children, we still find a significant difference, suggesting a decreased humoral immune response against pneumococcal polysaccharide antigen in a potentially larger group of children with recurrent bronchitis and normal serum $\operatorname{IgG}_{2}$ concentrations.

These findings are in general accordance with the results of Freijd et al. ${ }^{9}$ They reported significantly lower concentrations of $\mathrm{IgG}_{1}$ and IgG $_{2}$ specific type 6 a pneumococcal antibodies in a group of 15 children with recurrent otitis media compared with control children and healthy adults. In their patient group, specific $\delta$ pneumococcal antibody concentrations were higher in the $\operatorname{IgG}_{1}$ than in the $\mathrm{IgG}_{2}$ subclass, but $\mathrm{O}$ a similar pattern was also seen in their control group. However, in 15 healthy adults specific 을. pneumococcal antibody concentrations were higher in the $\operatorname{IgG}_{2}$ subclass. Their control group was younger than our control children and were $N$ selected from an ear, nose, and throat clinic if $\omega$ they had suffered from one or two episodes of $\mathcal{O}$ otitis media. It could be argued that their $\stackrel{0}{C}$ control group contained antibody deficient $\stackrel{\mathbb{D}}{\overparen{D}}$ patients. Our results are in accordance with those of Barrett $e t a l^{10}$ and Schatz and Barrett ${ }^{26} \underset{0}{0}$ who showed that antibodies against polysaccharide antigens in healthy children over the age of 3 years are mainly of the IgG $_{2}$ subclass.

The relatively small increase in pneumococcal antibodies after immunisation in both the 8 control and patient group confirms the findings of Douglas $e t$ al who reported a poor antibody response after pneumococcal vaccine up to the? age of 5 years. ${ }^{27}$ Paton et al reported a $2 \cdot 1$ to $2 \cdot 9$ fold increase in type 3 pneumococcal antibodies 
after immunisation in children aged 5 to 15 years. ${ }^{28}$ Barrett et al observed a threefold increase in IgG $_{2}$ type 3 specific pneumococcal antibodies after immunisation in adults. ${ }^{10}$ These observations suggest an increasing immune reactivity against pneumococcal vaccine with age.

The reason why patients show a greater rise in antibodies after immunisation, compared with controls, is not entirely clear. It might be explained in part by complexing of antibodies with injected antigens, thus reducing the amount of antigen available to stimulate B lymphocytes. This idea is supported by the finding that in the control group, the four children with a low initial concentration of $\mathbf{I g G}_{2}$ specific pneumococcal antibodies $(<10 \mu \mathrm{g} / \mathrm{ml})$ showed a mean $4 \cdot 2$ fold increase after immunisation.

Ambrosino et al found no significant difference in serum concentrations of IgG specific pneumococcal antibodies after immunisation between a group of respiratory infection prone children and controls. ${ }^{13}$ Perhaps differences were not obvious because total IgG was studied instead of IgG subclass specific responses.

No significant differences were observed in antibodies before and after immunisation in subgroups of patients with gastro-oesophageal reflux or high IgE concentrations compared with the whole group. The two IgG deficient patients showed both low antibody concentrations before immunisation $(<5 \mu \mathrm{g} / \mathrm{ml})$; in one there was an excellent and in the other no immune response after immunisation. Two of the four IgA deficient children had a good immune response after immunisation and three of them showed low antibody concentrations before immunisation.

IgG subclass measurements are considered important diagnostic tests in children with unexplained recurrent bronchitis. However, measurement of IgG subclass specific polysaccharide antibody concentrations before and after immunisation, compared with controls, is a more sensitive test to detect an antibody deficiency against polysaccharide antigens. Because of the relatively small antibody increase after immunisation with a pneumococcal vaccine, even in healthy children, immunisation with a $H$ influenzae type $\mathrm{b}$ vaccine may be preferable. Other investigators using this vaccine observed a definite increase in specific antibody concentrations in control children compared with infection prone patients. ${ }^{17}$

Although recurrent respiratory symptoms are a common problem in preschool children, most are due to increased non-specific bronchial hyper-reactivity evoked or increased by recurrent viral infections. In these children symptoms can be controlled by antiasthmatic drugs. However, in a small group of patients recurrent bacterial respiratory infections are suspected on a clinical, radiological, and serological basis. Our 25 patients were selected over a three year period from a tertiary paediatric reference centre and an asthma centre with 250 patients from all over Belgium. Although such children are frequently seen in specialised paediatric respiratory clinics, their prevalence in the population is relatively low.
As suspected in some children with IgG subclass deficiency, ${ }^{29} 30$ most of the patients in our study may have retarded development (immaturity) of the humoral immune system and repeat immunisation with polysaccharide antigens will be necessary to confirm a true deficiency. Prophylactic treatment with antibiotics or regular gammaglobulin replacement treatment may decrease respiratory symptoms and prevent serious pulmonary disease. However, controlled clinical trials will be necessary to confirm these possible benefits.

In conclusion, children with recurrent bronchitis show a decreased humoral immune response against pneumococcal type 3 polysaccharide antigen. This finding suggests that a defect in the humoral immune response against polysaccharide antigens is an important cause of recurrent bronchitis in childhood.

The work was supported by a grant from the Belgian National Fund for Scientific Research.

1 Schur PH, Borel H, Gelfand EW, Alper CA, Rosen FS. Selective gamma-G globulin deficiencies in patients with recurrent pyogenic infections. $N$ Engl f Med 1970;283: 631-4.

2 Stanley PJ, Corbo G, Cole PJ. Serum IgG subclasses in chronic and recurrent respiratory infections. Clin $E x p$ Immunol 1984;58:703-8.

3 Smith TF, Morris EC, Bain RP. IgG subclasses in nonallergic children with chronic chest symptoms. F Pediatr 1984;105: 896-900.

4 Smith TF, Ireland TA, Zaatari GS, Gay BB, Zwiren GT, Andrews HG. Characteristics of children with endoscopically proved chronic bronchitis. Am $f$ Dis Child scopically proved

5 Shackelford PG, Polmar SH, Mayus JL, Johnson WL,

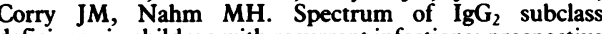
deficiency in children with recurrent infections: prospective study. F Pediatr 1986;108:647-53.

6 Noyes J, Woodmansee D, Chervinsky P. IgG subtype abnormalities with normal total IgG in a clinical allergy practice. Ann Allergy 1986;57:273-5.

7 Yount WJ, Dorner MM, Kunkel HG, Kabat EA. Studies on human antibodies VI. Selective variations in subgroup composition and genetic markers. $\mathcal{J}$ Exp Med 1968;127: $633-46$.

8 Riesen WF, Skvaril F, Braun DG. Natural infection of man with group A streptococci. Levels, restriction in class, subclass and type and clonal appearance of polysaccharidegroup-specific antibodies. Scand $\mathcal{F}$ Immunol 1976;5:383.

9 Freijd A, Hammarström L, Persson MAA, Smith CIE. Plasma antipneumococcal antibody activity of the IgG class and subclasses in otitis prone children. Clin Exp Immunol 1984;56:233-8.

10 Barrett DJ, Ayoub EM. IgG 2 subclass restriction of antibody to pneumococcal polysaccharides. Clin Exp Immunol 1986; 63:127-34

11 Siber GR, Schur PH, Aisenberg AC, Weitzman SA, Schiffman $G$. Correlation between serum $I_{g G}$ concentrations and the antibody response to bacterial polysaccharide antigens. $N$ Engl F Med 1980;303:178-82.

12 Umetsu DT, Ambrosino DM, Quinti I, Siber GR, Geha RS Recurrent sinopulmonary infection and impaired antibody response to bacterial capsular polysaccharide antigen in
children with selective IgG-subclass deficiency. $N$ Engl $\mathcal{F}$ Med 1985;313:1247-51.

13 Ambrosino DM, Schiffman G, Gotschlich EC, et al. Correlation between $\mathrm{G} 2 \mathrm{~m}(\mathrm{n})$ immunoglobulin allotype and human antibody response and susceptibility to polysachuman antibody response and susceptibility to polysac-
charide encapsulated bacteria. $\mathcal{f}$ Clin Invest 1985;75: charide $1935-42$.

14 Shackelford PG, Granoff DM. Antibody response of $\mathrm{IgG}_{2}$ deficient children to $H$. Influenzae type $b$ and pneumococcal types 3 and 23 polysaccharides. Pediatr Res 1987;21: 318A

15 Ambrosino DM, Siber GR, Chilmonczyk BA, Jernberg JB, Finberg RW. An immunodeficiency characterized by impaired antibody responses to polysaccharides. $N$ Engl Med 1987;316:790-3.

16 Wasserman RL. Failure of anti-pneumococcal antibody formation in patients with complete IgA deficiency and normal IgG levels. Pediatr Res 1987;21:319A

17 Ambrosino DM, Umetsu DT, Siber GR, et al. Selective defect in the antibody response to Haemophilus influenzae type $b$ in children with recurrent infections and normal serum IgG subclass levels. I Allergy Clin Immunol 1988;81: 1175-9.

18 Knutsen AP. Patients with IgG subclass and/or selective deficiency to polysaccharide antigens: initiation of a condeficied clinical trial of intravenous immune globulin. f Allergy Clin Immunol 1989;84:640-7. 
19 Gergen PJ, Mullally DI, Evans R. National survey of prevalence of asthma among children in the United States, 1976 to 1980 . Pediatrics $1988 ; 81: 1-7$.

20 Kjellman NI, Johansson SGO, Roth A. Serum IgE levels in healthy children quantified by a sandwich technique (PRIST). Clinics in Allergy 1976;6:51-3.

21 Jefferis R, Reimer C. Evaluation of monoclonal antibodies having specificity for human IgG subclasses: results of an
IUS/WHO collaborative study. Immunol Lett 1985;10: IUS/N232.

22 Buckley RH, Dees SC, O'Fallon M. Serum immunoglobulins: I. Levels in normal children and in uncomplicated childhood allergy. Pediatrics 1968;48:600-11.

23 Van der Baan S. Primary ciliary dyskinesia. Amsterdam: Kanters, 1985.

24 Gibson LE, Cooke RE. A test for concentration of electrolytes in sweat and cystic fibrosis of the pancreas utilizing pilocarpine by ionthophoresis. Pediatrics 1959;23:545-9. 25 Euler AR, Ament ME. Detection of gastroesophageal reflux in the pediatric age patient by esophageal intraluminal $\mathrm{pH}$ probe measurement (Tuttle test). Pediatrics 1977;60:65.

26 Schatz DA, Barrett DJ. Evolution of the subclass of IgG antibody to type 3 pneumococcal polysaccharide during childhood. Clin Exp Immunol 1987;70:449-55.

27 Douglas RM, Paton JC, Duncan SJ. Antibody response to pneumococcal vaccination in children younger than 5 years $\vec{\partial}$
of age. I Infect Dis 1983;148:131-7.

28 Paton JC, Toogood IR, Cockington RA, Hansman D. An J , Toogood IR, Cockington RA, Hansman D. Antibody response to pneumococcal vaccine in childre

29 Shackelford PG, Granoff DM, Madassery JV, Scott , Nahm MH. Clinical and immunologic characteristics of $\overline{\overline{2}}$ healthy children with subnormal serum concentrations: of IgG2. Pediatr Res 1990;27:16-21.

30 Shackelford PG, Granoff DM, Polmar SH, et al. Subnormal serum concentrations of $\mathrm{IgG}_{2}$ in children with frequent $\bar{\tau}$ infections associated with varied patterns of immunologic dysfunction. F Pediatr 1990;116:529-38.

\section{Kawasaki or not Kawasaki}

As there is no diagnostic test for Kawasaki disease the diagnosis must be made on clinical findings and the exclusion of other diseases. In my pocket notebook I carry the following list taken from the New England Fournal of Medicine (1986;315:388):

(1) Fever lasting at least five days plus four of:

(a) bilateral conjunctival injection

(b) red throat, or fissured lips, or strawberry tongue

(c) peripheral erythema, peripheral oedema, periungual desquamation, or generalised desquamation

(d) truncal rash

(e) cervical glands

(2) No other explanation.

In a multicentre study in the United States (Jane C Burns and colleagues, $\mathcal{F}$ Pediatr 1991;118:680-6) the clinical features were compared of 280 children with Kawasaki disease and 42 who had been referred because of a suspicion of that diagnosis but turned out to have something else. The something else was measles in 12 cases, a presumed but unidentified viral infection in another 12, a drug reaction in six, and group A $\beta$ haemolytic streptococcal infection in five. Of the other six children one each had juvenile chronic arthritis, a presumed bacterial cervical adenitis, and infection with adenovirus, influenza A virus, Epstein-Barr virus, and Leptospira interrogans.

The following findings occurred in a small minority of patients with Kawasaki disease and were significantly more common in the non-Kawasaki disease patients: conjunctival exudate, discrete lesions inside the mouth, exudative pharyngitis, and generalised lymphadenopathy. Several features were found more often in Kawasaki disease to a very high degree of statistical significance $(p \leqslant 0.001)$. They were injected bulbar conjunctivae, red or cracked lips, strawberry tongue, and perineal rash. This, however, is an excellent example of the distinction between statistical significance and clinical usefulness. Red lips, for instance, were found in $94 \%$ of cases of Kawasaki disease and $64 \%$ of the others. The difference is statistically very significant $(\mathrm{p}<0.001)$ but as a single piece of clinical information it is clearly useless for diagnostic purposes. What we need to know about any diagnostic procedure, either laboratory or clinical, is its sensitivity and specificity. The clinical features with a high sensitivity in the diagnosis of Kawasaki disease all seem to have a low specificity when taken as isolated findings. Perhaps certain combinations of features would be more specific but unfortunately these authors have not provided us with that information. Their conclusion is that the clinical criteria for the diagnosis of Kawasaki disease are unreliable. The diagnosis is made by using the specified clinical criteria and excluding other conditions but the decision to treat with immunoglobulin may have to be taken on the basis of an uncertain diagnosis. 